\title{
ACRL honors the 2007 award winners A recognition of professional achievement
}

\section{ACRL Excellence in Academic Libraries winners announced}

The winners of the 2007 Excellence in Academic Libraries Award are the Hostos Community College/CUNY Library, Bronx, New York; Elizabeth Huth Coates Library at Trinity University, San Antonio; and the Georgia Institute of Technology Library and Information Center, Atlanta.

Sponsored by ACRL and Blackwell's Book Services, the award recognizes the staff of a college, university, and community college library for programs that deliver exemplary services and resources to further the educational mission of the institution.

"Receiving an Excellence in Academic Libraries Award is

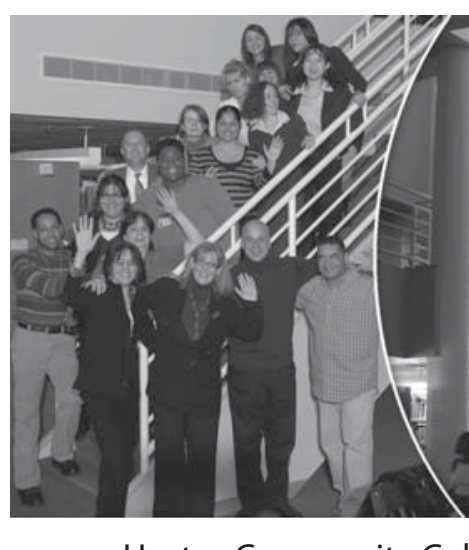

Hostos Community College/CUNY Library

faculty in developing new curricular design and revitalization through the development of new courses designed to teach information literacy, critical thinking, and computer literacy, and also by creating bilingual online learning environments," said Frances Maloy, chair of the 2007 Excellence in Academic Libraries Selection Committee and division leader of access services at Emory University.

"The library staff has absorbed the meaning of the life of the person for whom the institution is named through their bilingual,

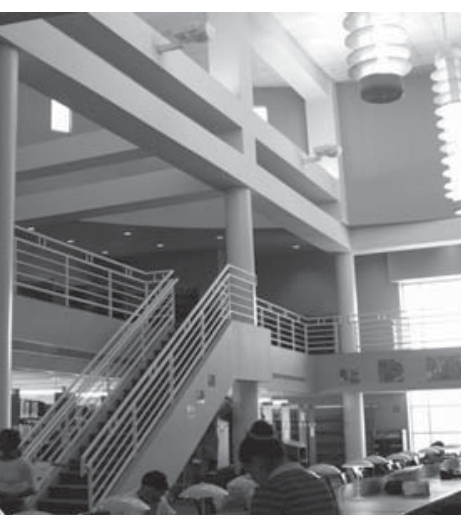

multilevel, and curriculum integrated information literacy program. Their efforts to produce the bilingual student literary and art magazine, Escriba!/Write! and to create an inviting and a national tribute to a library and its staff for the outstanding services, programs, and leadership they provide to their students, administrators, faculty and community," said Mary Ellen K. Davis, ACRL executive director.

\section{The Hostos Community College/CUNY Library}

The Hostos Community College Library, winner in the community college category, was recognized for putting the "community" in community college.

"The Hostos Library staff demonstrate exemplary partnership and leadership with bilingual student-focused environment in the library are also noteworthy."

"I cannot think of a better gift for our students and our community than to receive this national recognition of excellence for their library," said Lucinda Zoe, professor and chief librarian of the Hostos Community College/CUNY.

"It is a powerful message to send to our community here in the South Bronx-you have the best and you deserve it. Winning

Megan Griffin is ACRL program coordinator, e-mail: mgriffin@ala.org 
this award is truly a testament to the commitment of the library faculty and staff, as well as our college administration, to the library and our students."

\section{Elizabeth Hutb Coates Library at Trinity University}

The Elizabeth Huth Coates Library at Trinity University, winner in the college category, impressed the selection committee with its wide-ranging and innovative services for both students and faculty.

"Using the guiding philosophy of experimenting with 'all things new,' staff created user centric virtual and physical learning spaces as well as research spaces," said

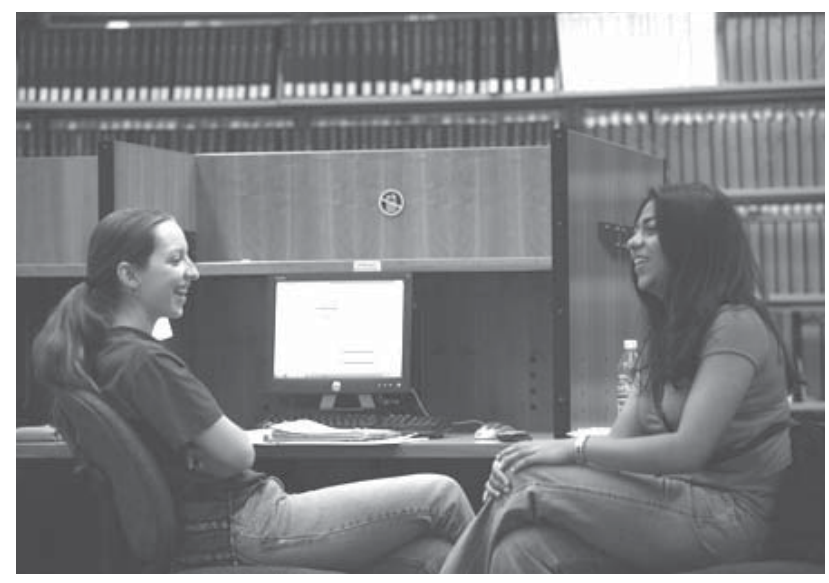

Elizabeth Huth Coates Library at Trinity University

Maloy. "The fully integrated information literacy program engages library users at all levels beginning with the first-year seminar to the 'Focus on Faculty' workshop series. The library's Web site incorporates chat reference, a downloadable library toolbar, federated searching and a comprehensive set of digital resources.

"The Coates Library also boasts a GIS librarian who leads the campus development of GIS research and teaching. Through the establishment of their own institutional repository called Digital Commons, they led the development of a consortial repository called the Liberal Arts Scholarly Repository. The library staff demonstrates that they know their community and extend themselves and library services to be wherever students and faculty are."
"The Trinity library staff and I are honored to receive this award," said Diane J. Graves, university librarian at Trinity University. "I am fortunate to have not only an amazing team of colleagues to work with, but an administration that supports the library when we want to try something innovative. Even more, Trinity's faculty and students have been a source of inspiration as they provide suggestions and feedback about what they want the library to do and be."

\section{Georgia Institute of Technology Library and Information Center}

The Georgia Institute of Technology Library and Information Center, winner in the university category, was selected for its impressive five-year transformation into being the heart and soul of the community.

"The library staff was guided by students and faculty throughout the design and implementation of engaging and creative new services to improve student learning, faculty teaching and research," said Maloy.

In partnership with Tech's Office of Information Technology, the library made imaginative use of public space for two information commons, a café, a presentation room, and a multimedia center, transforming the library into a place where the community gathers. Programs like CeLIBration, held during Freshman Welcome Week, and Tuesday Talks, a showcase for faculty research, invite the community to the library. The stimulating and engaging physical environment keeps them coming back.

"The library responded with virtual services as well," said Maloy. "Students and faculty told library staff to move swiftly to deliver digital content in evident and relevant ways. Staff responded with SMARTech and EPAGE to produce, disseminate and archive research created at Tech and are participating in national digital archive initiatives. Tech staff also created award winning software to improve access to and usability of electronic resources and Web-based services. The Georgia Institute of Technology library staff have 


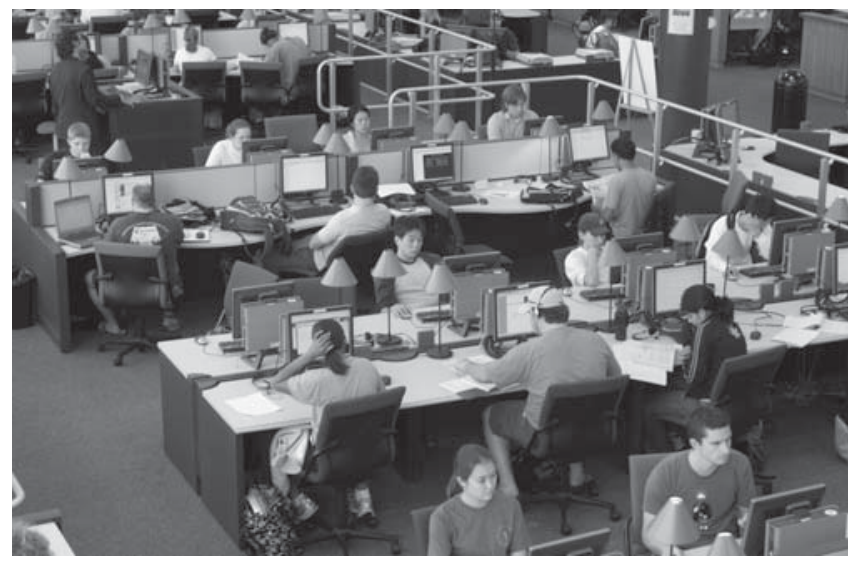

Georgia Institute of Technology Library and Information Center

forged a new model for the 21st century research library."

"I'd like to thank every member of the Library staff and faculty and our OIT and CETL colleagues who participate so effectively to advance the programs of the Library," said Richard W. Meyer, dean and director of Georgia Tech Libraries. "This award reflects your hard work, creative energy and commitment to the programs of Georgia Tech. I'm delighted and very proud to be a part of this library."

Each winning library will receive $\$ 3,000$ and a plaque, to be presented at an award ceremony held on each recipient's campus. The winners also will receive special recognition at the ACRL President's Program during the ALA Annual Conference on Monday, June 25, 2007, at 1:30 p.m. in Washington D.C.

\section{Hugh C. Atkinson award winner}

James G. Neal, vice president for information services and university librarian at Columbia University, has been named the 2007 winner

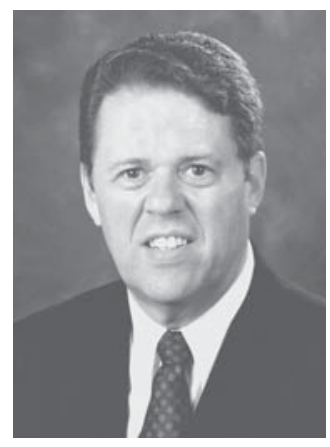

James G. Neal of the Hugh C. Atkinson Memorial Award. Neal will receive a cash award and a citation during the ALA Annual Conference at the Association for Library Collections and Technical Services (ALCTS) Awards Ceremony on Sunday, June 24, 2007, at 4:00 p.m.
Named in honor of one of the pioneers of library automation, the Atkinson Award recognizes an academic librarian who has made significant contributions in the area of library automation or management, and has made notable improvements in library services or research.

"Jim Neal unquestionably exemplifies the legacy of Hugh Atkinson!" said Carlen Ruschoff, Hugh C. Atkinson Memorial Award committee chair. "He is one of the most well-known and widely respected library leaders in the world today. He has become a recognized authority both nationally and internationally on copyright in relation to libraries and higher education. He has served as advisor to the U.S. Delegation at the WIPO Diplomatic conference. His leadership in shaping the national debate on intellectual property policy and his active role in government testimony has influenced the direction of public policy in this area.

"As a speaker and an author, Jim has been an effective influence on our profession. He has stimulated the thinking of librarians through his innovative and thought-provoking scholarship. He has, very deliberately, raised our profile on campuses, among publishers, and in government."

Neal has promoted models of publication that support open access to scholarly research, and he has been a guiding force behind the Scholarly Publishing and Academic Resources Coalition (SPARC). As library administrator, he has developed creative approaches to scholarly publication, framed innovative partnerships between libraries and scholars, and promoted an expansive vision of the roles of libraries in the scholarly endeavor.

Thomas C. Leonard, university librarian at the University of California-Berkeley, stated in his letter of support, "I am enthusiastic in saying that this statesman of the library world who has so often showed us our future, [is] an excellent choice for the Hugh C. Atkinson Memorial Award." 
"What an honor to be associated through this award with one of our field's most accomplished and exciting librarians," said Neal. "I am blessed to have had so many outstanding professional opportunities and to have worked with such remarkable colleagues."

In 1978, Neal received his Certificate in Advanced Librarianship from Columbia University, where he also received his M.S. in Library Science in 1973 and his M.A. in History in 1971. He received his B.A. in Russian Studies from Rutgers University in 1968.

The Hugh C. Atkinson Award is jointly sponsored by four divisions of ALA: ACRL, ALCTS, Library Administration and Management Association (LAMA), and Library and Information Technology Association (LITA) The award is funded from an endowment established to honor Atkinson.

\section{Casey named 2007 DLS Haworth Press Distance Learning Librarian Conference Sponsorship Award Winner}

Anne Marie Casey, associate dean of libraries at Central Michigan University (CMU), has been named the 2007 recipient of ACRL's Distance Learning Section (DLS) Haworth Press Distance Learning Librarian Conference Sponsorship Award. This annual award honors an ACRL member working in the

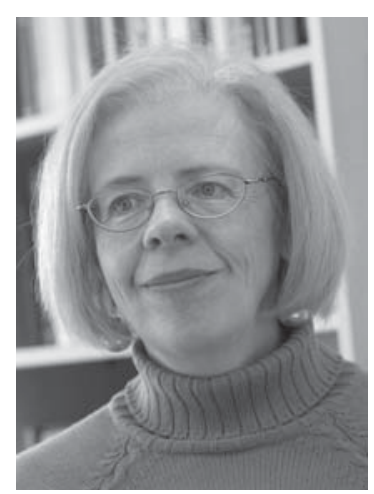

Anne Marie Casey field of, or contributing to the success of, distance learning librarianship or related library service in higher education.

"Anne Marie Casey has a long and distinguished record of service in the Distance Learning Section and in off-campus librarianship," said Connie Hildebrand, chair of the DLS award committee. "Her professional activities show an outstanding contribution to this field."

Casey's numerous DLS activities include serving as chair (2001-02), having multiple appointments as member and chair of the Social Events Planning Committee (2003-08), and serving as secretary/archivist (1995-97). She currently serves on the Michigan Library Association (MLA) Board of Directors and was member-at-large of MLA from (2003-05). Casey was vice-chair/chair of the ACRL Louisiana Chapter (1983-84).

Prior to becoming associate dean of libraries at CMU, Casey served as CMU director of off-campus library services and coordinator for librarian services/off-campus librarian (1991-99).

Casey received her B.A. from the University of Massachusetts in 1977, and earned her M.A. from the Catholic University of America in 1979. She received her A.M.L.S. from the University of Michigan in 1981.

Haworth Press, Inc., sponsor of the award, will present the $\$ 1,200$ award and plaque at the ALA Annual Conference during the DLS program on Saturday, June 23, at 10:30 a.m.

\section{Elmborg and Hook win 2007 llene F. Rockman Publication of the Year award}

James K. Elmborg, associate professor of the School of Library and Information Science at the University of Iowa, and Sheril Hook, coordinator of instructional services at the University of Toronto-Mississauga, have been chosen as the winners of ACRL's Instruction Section (IS) Ilene F. Rockman Publication of the Year Award for their book, Centers for Learning: Writing Centers and Libraries in Collaboration, Publications in $\mathrm{Li}$ brarianship \#58."

This annual award honors Rockman's professional contributions to academic librarianship in the area of information

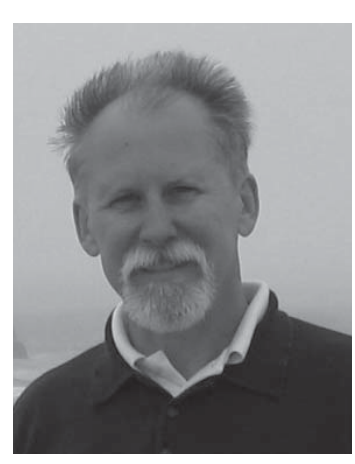

James K. Elmborg literacy. The award recognizes an outstanding publication related to instruction in a library environment published in the preceding two years. 
Emerald Group Publishing Limited, sponsor of the award, will present the $\$ 3,000$ award and plaque during the 2007 ALA Annual Conference at the IS program on Sunday, June 24, 2007, at 1:30 p.m.

"Considered as a whole, Centers for Learning represents a cogent, original unification of

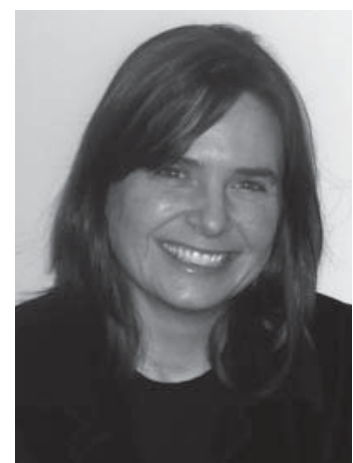
theory with multifaceted practice," said Kathleen Gallagher, IS awards committee chair. "Elmborg and Hook have assembled a compelling case not only for treating research and writing as a hoSheril Hook listic process, but for leveraging the unique strengths of writing centers and information literacy programs to improve student mastery of the process."

The publication provides an in-depth look at a particular collaboration that promises to significantly enrich information literacy theory and related instructional practices. Building in part on the literature of the 1990s that explored the relationship between bibliographic instruction, composition pedagogy, and their respective programming models, Centers for Learning reflects the maturing of theory and practice that has occurred in both domains in the context of more than a decade's change in higher education.

"Part One," written by Elmborg and Hook, lays a solid foundation for library/ writing center partnerships in the shared theories and common practices of instruction librarians and writing instructors. It also establishes the framework within which to consider the case studies that make up "Part Two" of the book. These uniformly strong contributions, many coauthored by librarians and writing center directors, articulate logical points of collaboration and highlight successes without concealing the difficulties inherent in reaching across campus units. The editors' insistence on real-world part- nerships avoids the oversimplifications of the "how-to" genre in favor of showcasing the diversity of practice that can grow from seeds of shared purpose.

\section{ACRL STS Oberly Award goes to AgEcon Search}

AgEcon Search has been selected as this year's recipient of the ACRL Science and Technology Section (STS) Oberly Award for Bibliography in the Agricultural or Natural Sciences.

AgEcon Search cofounders Louise Letnes, librarian at the University of Minnesota, and Patricia Rodkewich, former reference bibliographer at the University of Minnesota, and contributor Julie Kelly, reference librarian and instruction coordinator at the University of Minnesota, will receive a plaque and cash prize at the ALA Annual Conference during the STS Program, Monday, June 25, 2007 , at 8:00 a.m.

"AgEcon Search is an outstanding example of a successful and highly used subject bibliography in electronic format," said award committee cochairs Martin Kesselman and Paul Kelsey. "AgEcon Search is a wonderful example of an effort to manage the grey literature of a discipline in an accessible and easily used format."

AgEcon Search includes publications emanating from more than 150 academic institutions, professional societies, and government agencies, and offers full-text access to literature not always covered in the major agricultural and economic indexes. With more than 144,000 visits in 2005 and 1.25 million document downloads since 2001, AgEcon Search continues to offer enormous benefits to researchers in the field of agricultural economics.

AgEcon Search is maintained and Cosponsored by the University of Minnesota Libraries, the Department of Applied Economics at the University of Minnesota, and the American Agricultural Economics Association.

The Oberly Award was established in 1923 in memory of Eunice Rockwood Oberly. This biennial award is given in odd-numbered years 


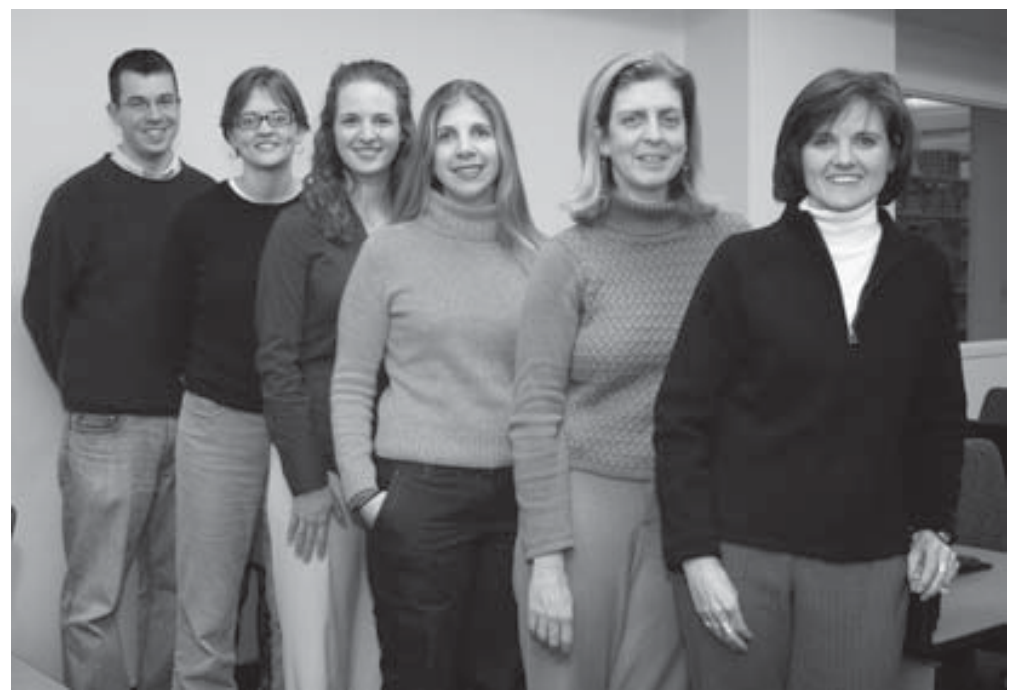

Project participants for University of North Carolina-Chapel Hill (UNC-CH) Community Workshop Series include (left to right): Grant Lynch, program co-coordinator, master's student at School of Information and Library Science, UNC-CH; Jennifer Lohmann, LIFT Library, Durham County Public Library; Amy Thompson, program co-coordinator, master's student at School of Information and Library Science, UNC-CH; Kim Vassiliadis, instruction design and technology librarian, University Library, UNC-CH; Margot Malachowski, branch librarian, Carrboro Cybrary; Lisa Norberg, director of public services, University Library, UNC-CH. Not pictured: Susan McClure, head of reference at the Chapel Hill Public Library, and Jake Lehrer, branch librarian at the Carrboro Branch of the Orange County Public Library

for the best English-language bibliography in the field of agriculture or a related science.

\section{ACRL announces 2007 IS Innovation award winner}

The Community Workshop Series created by the University of North Carolina-Chapel Hill (UNC-CH) Library's Instructional Services Department has been chosen to receive the 2007 ACRL Instruction Section (IS) Innovation award. Sponsored by Lexis-Nexis, the annual award recognizes a project that demonstrates creative, innovative, or unique approaches to information literacy instruction or programming.

"The Community Workshop Series is a programming innovator, a model of creativity and quality we found especially compelling for its multi-level partnerships and multiple innovations," said Kathleen Gallagher, IS awards committee chair. "A quick glance at the statistics, too, provides strong evidence of the impact the workshop series is having. Since the program's inception in March 2005, 248 class sessions have reached 1,490 participants and engaged 58 volunteer instructors. It is clear that the success of the program is due to the strength of the concept, the commitment of the partners, and the attention to detail in all aspects of the planning and delivery."

The Community Workshop Series brings information literacy programming into the community through a partnership between the University Library and four local public libraries-Chapel Hill Public Library, the Carrboro Cybrary and Carrboro Branch Library, and the Durham County Public Library. The UNC Library's Instructional Services Department, which initiated and manages the program, recruits and trains instructors from the library, from the UNC-CH School of Information and Library Science (SILS), and from undergraduates seeking to fulfill the UNC-CH service learning requirement. The public libraries produce publicity, manage registration, and provide facilities for the classes.

The program represents an opportunity for UNC-CH's public library partners to offer a service they would not otherwise have the staff to provide, while for the University library it represents "an important effort" in its mission "to serve the local community and the people of North Carolina."

On the UNC-CH campus, the program has also built bridges between the library, SILS, and the Service Learning Office, while actively involving the library in the instructional development of future librarians and the service learning of undergraduates.

A prize of $\$ 3,000$ and a plaque will be presented to the project team during the IS program on Sunday, June 24, 2007, at 1:30 p.m. z 